\title{
The Role Of Narrative and Social Networks in Thwarting Violence and Sexual Abuse in Young People's Lives
}

DOI:

10.1093/bjsw/bcz114

\section{Document Version}

Accepted author manuscript

Link to publication record in Manchester Research Explorer

\section{Citation for published version (APA):}

Gadd, D. (2019). The Role Of Narrative and Social Networks in Thwarting Violence and Sexual Abuse in Young People's Lives. The British Journal of Social Work. https://doi.org/10.1093/bjsw/bcz114

\section{Published in:}

The British Journal of Social Work

\section{Citing this paper}

Please note that where the full-text provided on Manchester Research Explorer is the Author Accepted Manuscript or Proof version this may differ from the final Published version. If citing, it is advised that you check and use the publisher's definitive version.

\section{General rights}

Copyright and moral rights for the publications made accessible in the Research Explorer are retained by the authors and/or other copyright owners and it is a condition of accessing publications that users recognise and abide by the legal requirements associated with these rights.

\section{Takedown policy}

If you believe that this document breaches copyright please refer to the University of Manchester's Takedown Procedures [http://man.ac.uk/04Y6Bo] or contact uml.scholarlycommunications@manchester.ac.uk providing relevant details, so we can investigate your claim.

\section{OPEN ACCESS}




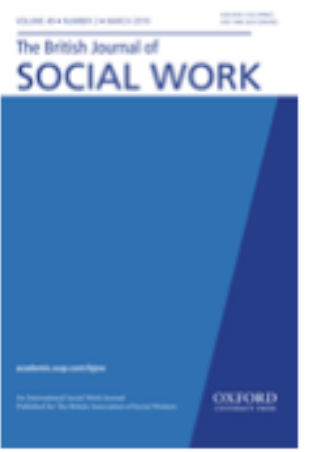

Draft Manuscript for Review. Please complete your review online at http://mc.manuscriptcentral.com/oup/bjsw

\section{THE ROLE OF NARRATIVE AND SOCIAL NETWORKS IN THWARTING VIOLENCE AND SEXUAL ABUSE IN YOUNG PEOPLE'S LIVES}

\begin{tabular}{|r|l|}
\hline Journal: & The British Journal of Social Work \\
\hline Manuscript ID & BJSW-18-118.R3 \\
\hline Manuscript Type: & Original Article \\
\hline Keywords: & $\begin{array}{l}\text { Sexual abuse, Social networks, Resilience, Qualitative methods, } \\
\text { Quantitative methods }\end{array}$ \\
\hline Subject Categories: & Families, Children and Young People \\
\hline
\end{tabular}

\section{SCHOLARONE ${ }^{m}$ \\ Manuscripts}




\title{
THE ROLE OF NARRATIVE AND NETWORKS IN THWARTING VIOLENCE AND SEXUAL ABUSE IN YOUNG PEOPLE'S LIVES
}

\begin{abstract}
Combining narrative analysis with social network analysis, this article analyses the case of a young Swedish female who had been physically and sexually abused. We show how she became trapped in an abusive relationship at the age of 14 following social work intervention in her family home, and how she ultimately escaped from this abuse aged 19. The analysis illustrates the significance of responses to interpersonal violence from the social networks that surround young people; responses which can both entrap them in abusive relationships by blaming them for their problems and enable them to escape abuse by recognising their strengths and facilitating their choices. The article argues the case for social work approaches that envision young people's social networks after protective interventions have been implemented. The article explains that such an approach has the potential to reconcile the competing challenges of being responsive to young people's needs while anticipating the heightened risk of being exposed to sexual abuse young people face when estranged from their families or after their trust in professionals has been eroded.
\end{abstract}

Key words: Ending violence, Narrative analysis, Responses, Sexual abuse, Social networks, Social network analysis

\section{Introduction}

Revelations about the sexual abuse of children and young people in community-based organisations proliferate in many Western countries (Campbell, 1988). Allegations have focussed on the church (La Fontaine, 1998; McCluskey, 2000), institutional care providers (Barter et al, 2003; Gallagher 2000), schools (Timmerman, 2003), music and entertainment 
providers (Furedi, 2013), as well as football clubs (NPCC, 2018). Critical attention has also focussed on the police and social services who, in some UK cases, have hesitated to investigate accusations of sexual exploitation made by vulnerable young women against men from minority ethnic groups (Jay, 2014). Consequently, many of the questions that became pertinent in the 1980s - about the reach of social workers into the private lives of families and the risk of putting children and young people in greater danger following social work intervention - remain pertinent today (Campbell, 1988; Munro, 2011).

What has improved over those intervening years, however, is the availability of research on young people's perspectives on abuse, disclosure and professional intervention. We know now, as was not so widely appreciated then, that children are aware of violence in their homes and are frequently troubled and traumatised by it, even when adults think they have been able to conceal it behind closed doors (Holt et al, 2008; Mullender et. al., 2002; Överlien and Hydén, 2009; Stanley et al, 2012). A recurring lesson from much research is that many young people understate the power imbalances between themselves and adults, and hence overstate their own failures to intervene to stop violence from repeating and their complicity with perpetrators who encourage them to blame themselves and/or other victims (Gadd et al, 2015; Worrall et al, 2008). Such feelings of complicity are complicated further when young people are coerced or pressurised into sexual practices with adults out of fear, for protection, or because they do not want to hurt another person's feelings (Mollon, 2000; Miller, 2008; Firmin, 2011; Reavey and Gough, 2000). Consequently, when young people do disclose experiences of abuse, they usually do so to someone they know will keep their confidence, choosing their peers more often than adults because it gives them more discretion over what, if anything, happens next (McElvaney, 2015). Young men who are already in trouble with the law, often say they prefer to 'deal' with issues relating to abuse in relationships 'alone', fearing social work or police intervention will make matters works (Gadd et al., 2015), while young 
women whose relationships with their families have become fractious or who have been placed in institutional care can find themselves at heightened risk of violence and abuse when they enter relationships with much older men who promise to 'look after' them (Barter et al., 2009).

It has thus become apparent that to intervene effectively in cases of abuse, professionals must anticipate the responses of young people themselves as well as those in their social networks, including their family, friends, and, where applicable, professional carers (Münger, 2016; Sandberg 2016). Pointing to the continued failure of social work and criminal justice interventions that concentrate exclusively on victims and offenders, Firmin (2018a), argues that if they are to avoid merely displacing the problem of peer-on-peer abuse to harder to reach contexts, professionals must engage with extra familial dynamics, such as harmful norms in peer groups, schools and public spaces. Rayment-McHugh et al. (2015) argue similarly in their review of studies of sexual violence in conflict zones, remote and marginalised communities and religious and state intuitions. They caution against interventions that presume that child sexual abuse has been 'organised' secretively from the top-down, and instead note that children are generally placed at risk by a series of breakdowns in individual, situational and ecological constraints that leave them vulnerable to the exploitation of perpetrators who operate in plain sight by assuming legitimate roles in fractured communities.

In sum, the emerging consensus is that, in order to be effective in thwarting violence and abuse against young people, social workers need to extend their focus beyond family intervention to incorporate the wider networks in which children and young people are themselves embedded. They will need also to contemplate how the responses of the various members of these networks contribute to young people's vulnerabilities to abuse and resilience against it. This is because acts of violence and sexual abuse, even though they often 
occur in private places, are not isolated incidents taking place in a social vacuum. Rather they are social actions given meaning in specific social contexts; meaning that is renegotiated by multiple social actors within wider social networks over which young people have limited control. Young people's social networks can make it very difficult for them to fully identify and articulate what is abusive about the relationships in which they are enmeshed without placing themselves and others in danger, or risking social isolation and estrangement. When young people begin to reveal problems in their relationships that are potentially suggestive of abuse, responses from members of their networks can vary enormously. Authorities may be alerted, but so might potential abusers. Secrets can be shared only to be further obscured. What members of a young person's social network share with each other and professional service providers about potential abuse may depend upon whether they construe the parties involved as 'perpetrators' and 'victims', 'adults' 'young people' and/or 'children', 'carers' and 'cared for', 'partners', 'friends' or 'lovers', 'innocent parties' or 'trouble-makers'. These responses can dramatically influence, or fail to influence, the social and material conditions victims must overcome to break free of abusive relationships and harness the support of peers, family members and professionals alike.

\section{Methodology}

We explore these processes by drawing on an interview with a young woman we have called 'Mary'. Mary was a participant in a pilot study conducted by Margareta Hydén at a nongovernmental (NGO) church-based organisation for vulnerable children, young people and their families in Sweden. The primary aim of the study was to investigate how young women's mental health problems - including depression, self-harm, eating disorders, insomnia - were affected by their social network's responses to them. The study conformed to internationallyaccepted ethical and professional guidelines for social work research as well as the requirements of the Regional Ethical Board in Linköping, Sweden (2014/105-31). The analysis 
that appears in this article has been shared and discussed with 'Mary'. Five young women aged 17-23 participated. All five women met the primary inclusion criteria in that they had suffered from severe health problems. The interviews lasted between 60-90 minutes and were 'tellerfocussed' in style (Hydén, 2014). The participants were introduced to a 'network map', consisting of a circle, divided into four parts - family, relatives, friends and working life/studies, - and asked complete it with details of their own network members. The women were then invited to talk about their health problems in response to open questions, such as: 'Can you tell me about $x$ ?' 'Can you develop that a bit further?' or 'Could you give me an example of what you just said?'. Finally, the women were asked to describe responses to their health problems from their social networks. The data was transcribed, checked for accuracy and translated from Swedish into English, enabling all three authors to analyse it. The first round of analysis revealed that all five of the young women had been subjected to physical, psychological or sexual violence. At first, we deployed the principles set out by Riessman (2008) for conducting a thematic narrative analysis. Then, in our next round of analysis, we identified various stories about abusive relationships in all of the interviews; stories that revealed how individual agency was performed and curtailed within the parameters instated by social networks as they responded to particular incidents of violence.

Mary was the participant who presented the most detailed narrative. She was 23 years old when she was interviewed by Margareta Hydén in the offices of the NGO, where she was a regular visitor. During the interview Mary described experiences of being exposed to repeated violence and sexual abuse by a leader at a youth club who became her foster carer after she had been removed from her family home by social services. Mary mapped out all of the people in her social network while the abuse was occurring and when she tried to escape it, including her friends, family members, professionals and her abusers. We decided to single out Mary's narrative for intensive study of the relationships between a young woman's exposure to 
violence and the various responses social networks offer. Inevitably, one cannot draw inferences about the prevalence of such networks and responses from a single case and the need to preserve anonymity also limits what can be said about typicality. However, as we show, the relational dynamics Mary's case reveals do enable certain conceptual hypothesis to be illuminated - dynamics which can be further explored in social work practice and which provide 'real-life' context to the study of abusive relationships, the boundaries of which often permeate ambiguously into the wider social contexts of power relations (Yin and Campbell 2003).

Mary's story comprised three phases - each defined, not only by life stage but also by her social network's responses to what she experienced. These phases were: 1) Becoming the 'Problematic Child' in her Family Home; 2) Teenage Grooming by the Youth Club Leader, and 3) Escaping Violence and Abuse as a Young Adult with the Support of a Teacher, Psychologist and an NGO. Our subsequent narrative analyses focused on what Mary's stories revealed about the choices with which she was confronted and how the configuration of her social networks shaped those choices at the three key time points in the history of her victimization.

After the qualitative narrative analysis was complete, 'life ego-networks' (Crossley et al., 2015) were constructed for each of these three phases using STATA software (Grund, 2015). These life ego-networks, as represented below, depict the various actors (grey nodes) in Mary's life, as well as her affiliations marked by dashed lines to various institutions (black nodes) including her school, family, the youth club where the man who groomed her for sexual abuse worked, and the NGO that facilitated her escape from him (see Figures 1-3). The networks were also colour-coded to convey the quality of each of Mary's relationships, as she perceived them, at the time of the interview: neutral (grey), positive (green), and negative (red). 


\title{
The Case of Mary - a Story in Three Phases
}

Phase 1: Becoming the 'Problematic Child' in her Family Home

Though Mary began her interview by saying she was worried there would not be enough time to tell her story, the interviewer's assurances encouraged her to nevertheless start 'from the beginning'. In her case it meant living with her mother who was addicted to alcohol and a father who drank heavily and while drinking was violent, until he moved out and another man, who appeared to see Mary and her sister as an inconvenience, moved in.

\begin{abstract}
My parents, they drank a lot during my and my younger sister's childhood... My mum was an alcoholic. My father was very violent. He hit me when I was little. He left when I was seven. Then my mum met another man. He was not very happy about me and my sister's existence. My mum started to drink even more because of everything around her.
\end{abstract}

Figure 1: Network Around Mary During Childhood

Figure 1 depicts Mary's social network as a young child. She had four major affiliations at this stage. Family 1 refers to Mary's biological family. In contrast, Family 2 refers to the new family that formed when Mary's biological father left and the man who became known as her stepfather moved in with her mother. At this time, Mary was also attending a nursery and became acquainted with members of a healthcare unit there - her third set of affiliations. There, Mary experienced most of the relationships to the adults in her network in a negative (red) or neutral (grey) way. In addition to her mother, sister (Sophia) and stepfather, all of whom lived with Mary, there were other relations on her mother's family's side (aunt, grandmother, grandfather). Two professionals at the nursery were to connect Mary to another -fourth - network of healthcare workers who attempted to provide a diagnosis of behavioural 
issues they had observed. Consequently, the picture that emerged from the narrative and network analyses was one in which Mary was cast as the 'problematic child' by virtually all the adults she knew. Hence, as a young child her network was defined by predominantly negative relationships (red lines) with adults who otherwise had positive relationships (green lines) with each other when she was not around. By way of contrast, the only relationships Mary regarded positively at this time were those with her sister, Sophia, and her maternal grandmother - two people who had little decision-making power and who were both loyal to her mother.

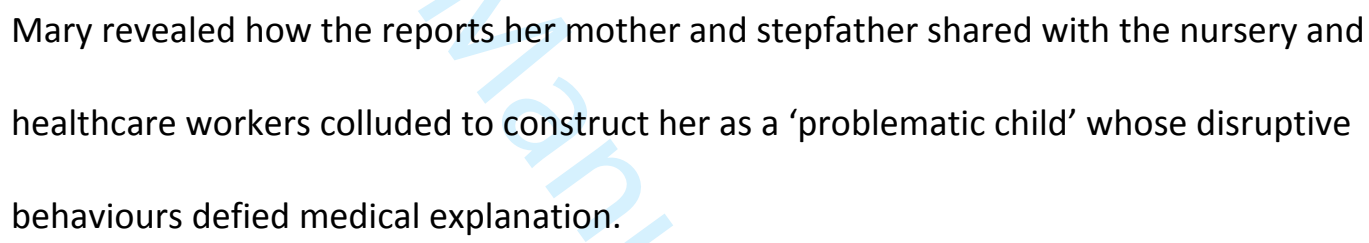

I was very problematic as a child. I hurt myself from an early age. At age four I started to bite myself, tear my hair, was very angry at everything and everyone, foremost with myself. They noticed that at the nursery. I could scream for hours. I could bite myself; bang my head against the wall, those sorts of things. My mum gave the impression of being very fragile. At the nursery they felt sorry for her: 'Your child is so problematic. We can understand if you are tired'.

Once the health care examination established there was nothing medically 'wrong' with Mary, the reasons for blaming her for her mother's fragility accumulated. The nursery took on extra staff (depicted by the worker in Figure 1) to cope with Mary, but when her behaviour failed to improve the 'problematic child' label stuck. Aged seven, Mary was placed in a special class for children with learning disabilities because she had been rude to a teacher to whom she was later returned when no learning difficulties could be detected. As no questions were asked about her home life, Mary became increasingly angry. As a young teen she confronted her 
mother about what a bad parent she was when under the influence of alcohol. Her mother and stepfather refuted the accusation, however, reiterating that Mary was the real problem. On one occasion Mary's stepfather - who had since had two children with Mary's mother responded by hitting Mary. On another, he tried to lock Mary in the closet. With her 'cry for help' unheard, Mary 'just did things worse' in increasingly erratic bids to get someone to either question what was wrong or otherwise convert the stigma associated with being 'problematic' into the acclaim of a 'wild child'. As a young teen, Mary cut herself and took some of her mother's pill and she:

... had sex with a lot of different men, sold sex, stealing and was caught by the police. But I didn't care. And they [social services] threatened me. I was the problem. They pitied my mum... I tried to say that I am doing... this because my mum subjects me to this and doesn't help me. Everything was a cry for help.

After one big fight with her mother, following a bout of self-harming, Mary contacted social services herself and told them about her problems, asking if they could help her to leave. Social services then contacted her mother, a response that Mary perceived not as protocol, but as a betrayal of her trust. Social services responded by 'threatening' to place Mary in institutional care if she did not change her behaviour, leading Mary to the conclusion that her family and the professionals had conspired against her.

Phase 2: Teenage Grooming by the Youth Club Leader

Mary's cry for help was eventually heard when she and a likeminded friend were caught vandalising a shop and the shop owner referred them both to a local youth club, approved by social services and directed by 'Bill'. Bill described himself as a 'therapist' but had no formal training. Mary became very close to Bill. He was the first adult to endorse her view that her 
mother - and not she - was the 'problematic' one in her family and this instantly established a bond of trust between them. Bill's response to Mary's disclosure about her home life made her feel 'special', in part because back then she did not know that he had the same kind of 'special relationship' with the other girls at the youth club, but also because in introducing Mary to his female partner (Denise) Bill positioned himself as a father figure. As she got to know Denise, Mary began to believe she had 'at last found a mother', an adult woman who 'cared for me in a way my own mother had not'. Mary wondered if she also had found a bigger family, comprising the many other young people at the youth club, young people like her who had also been identified as 'problematic children', some of whom attended with their parents. Indeed, it was a family of some public standing. Bill was widely recognised a local hero; the police and social services having commended him for 'saving young people's lives'.

Unfortunately, Mary's new sense of belonging diminished when Denise left Bill, breaking off all contact with Mary. This loss was a 'major blow' for Mary but not the worst, for Bill expected her, then aged 15, to take Denise's place as his new partner. What had begun, when Denise had still been around, as touching, requests to stay over at the club and pestering for sex - all offered under the pretence of 'therapy' in which Mary had to confess how 'dirty' she was became much more brutal after Denise left. At first, Mary thought Bill was just 'joking' or 'testing' her, but she soon discovered how serious he was. Bill convinced social services that Mary was 'sick' and needed '24-hour care', successfully negotiating a position as Mary's foster carer. Having fractured her connections with her biological and stepfamilies, Mary had 'nowhere to turn' to escape Bill's forceful sexual advances.

As Figure 2 illustrates, Mary's positive affiliations at age 15 were little different to those she had as an infant: they were only to her sister, Sophia (green line), and her maternal grandparents and her paternal grandmother. Both Mary and her sister had negative (red line) 
relationships with their stepfather and mother. Mary and Sofia had a neutral (grey line) relationship with their half-siblings in their mother's new marriage (Eric and Linnea) and an almost non-existent relationship with their biological father.

\section{Figure 2: Network Around Mary At Youth Club}

It was against this backcloth of a defunct social network that the youth club was able to take a significant role in Mary's life. As Bill began to dominate her life, Mary came to experience her relationships to most of the other young people in the youth club in a neutral way (grey lines), even though they were in many ways like her. Some of them did not pay much attention to Bill's sexual pestering, affording Mary no protection. Others whom Bill had also sexually abused were too afraid to say anything and unwilling to help Mary. One of the boys (Raul) who attended the youth club was apparently Bill's 'right-hand man' and reported to him what was being said in the group. Since the board members - most of whom were men - were very satisfied with Bill's work, his position had some official endorsement, complicating Mary's assessment of him, since she respected the board's authority (green lines). Mary was disinclined to speak to the social workers (red lines) she knew since they had taken her mother's 'side' and hence could not be trusted; a view compounded by their decision to designate Bill as her authorised foster carer.

As Figure 2 reveals, Mary's removal from her family home cast her into a wider network that delimited her chances of accessing professionals and others in positions of adult authority capable of helping her navigate the dangers she was experiencing. This wider network, that had been formed by the initial responses to Mary when she was cast as 'problematic child', ultimately resituated her in a highly abusive 'relationship' that was confusingly cast as both pseudo-parental and an intimate partnership. This confusion was exploited by Bill who would 
'rape' Mary before publicly demeaning her, spitting at her in front of other young people, and 'punishing' her 'all the time'. Aged 16, Mary was 'totally exhausted'.

Phase 3: Escaping the Violence and Abuse as a Young Adult with the Support of a Teacher, Psychologist and an NGO

As one of his 'special' cases, Bill required Mary - aged 16 - to attend an upper secondary school with a reputation for developing the skills of underperforming pupils. This presented Mary with an unexpected opportunity to expand her social network and get access to a support network that eventually helped her to escape from Bill. When a teacher at the upper secondary school who Mary was fond off noted Mary was late, Mary:

just broke down, thought it was my fault as usual, started to cry... I think it was because she... had told me so many times that I was 'a great and talented pupil'. She meant a lot to me. Now I had disappointed her. To my great surprise she almost broke down too! She apologised for her remark, telling me that she hadn't meant to criticise me... I just... couldn't stop crying... couldn't cope with so much kindness. She... asked me how I was doing and asked if I wanted to talk to the psychologist at the school.

Somewhat reluctantly, Mary agreed to see the psychologist - Eva - who echoed her teacher's observations about how 'good' Mary was as pupil and as a friend to other pupils.

Figure 3: Network Around Mary While Leaving Bill

As Figure 3 reveals, after a decade of being isolated as a 'problematic' child, Mary finally secured some positive connections to adults willing and able to help understand and redress 
the relationships that were causing her problems. Eva referred Mary to an NGO where she met other troubled young women and professionals committed to helping her. While, the negative relationships with her mother, stepfather and social services persisted, the new relationships induced a change in the structure of Mary's network that slowly engendered a dramatic outcome. Gradually, the new positive relationships began to multiply and insulate Mary from the negative ones, but she had still to come to terms with the realisation that her 'relationship' with Bill was not a relationship at all in the romantic or intimate sense of the term. Mary was encouraged by the NGO workers to report Bill to the police, but she refused to do so, in part because she knew other cases brought by young women that had failed in court after other members of the youth club had spoken in Bill's favour. No less significant in Mary's reluctance, however, was the mixed feelings she had about Bill. She felt partly responsible for what he had exposed her to, still cared about him, and still found him 'attractive' in some ways. Mary also worried about the stigma for them both of exposing the sexual elements of their relationship. So, she decided, at first, to 'set limits' for Bill. This meant attempting to change their 'relationship', as she perceived it, by bringing an end to the sexual element of it. Though the NGO would have preferred Mary to go straight to the police, they agreed to support her for one month while she attempted to 'break-up' with Bill.

Unfortunately, Bill responded to Mary's efforts to terminate the sexual aspects of their relationships by becoming more abusive, touching her in provocative ways, calling her a 'filthy bitch' who had been 'wasting' his 'time', screaming at her and dragging her around in front of other young people at the youth club. The NGO nevertheless remained supportive of Mary and secured a place for her to live. Once the month was up, Mary agreed to report Bill to the police. This report ultimately led to his conviction and a lengthy custodial sentence. Six years later, aged 23, Mary had moved in with her paternal grandmother, regenerating one part of her family social network (see Figure 3). Mary still had limited contact with her mother and 
none with her father. She had entered a relationship with a male intimate partner whom she regarded as 'loving'. She had also found self-confidence through academic study, partly funded through victim compensation. Mary explained that she had achieved success 'against all odds' and discovered that 'when you study, your past does not matter... I have to let that go.'

\section{Discussion \\ Developing Agency}

During her youth, Mary's links to her family of origin barely changed. What did change was the wider network structure in which she was embedded. This development became pertinent as she entered what has been conceptualized by Arnett (2004) as 'emerging adulthood', i.e. the years between 18-25, a phase in the Western human life-course that presents key opportunities to transform one's trajectory and chances, including identity exploration, trying out new possibilities, instability and self-improvement and reflection. 'For some young people who have grown up in poor or chaotic families, emerging adulthood represents a chance to transform their lives in dramatic ways', Arnett (2004, p. 23) argues. During this phase, the life course is destabilized for many young people and, as we have shown, their social networks can evolve suddenly. Consequently, their choices become less predictable, something that can be both 'tremendously liberating' and 'terrifically burdensome', 'depending on the resources at the person's disposal' (Côté 2002, p. 118).

Mary, as we have shown, took advantage of the 'window of opportunity' the changing conditions of her emerging adulthood years had to offer. The expansion of her social network introduced her to professionals willing and able to provide recognition for her strengths without exploiting her. These professionals proved capable of creating the emotional space Mary needed to reflect upon the nature of her 'relationship' with Bill, thus making it possible to scaffold her decisions to leave him and to ultimately support his prosecution. As some 
people were added to her social network and others were marginalised within it, the meaning of what Mary had experienced was renegotiated. These changes in the constitution of Mary's social network impacted upon the scope she had for developing her own agency in response to the various abuses she was being exposed to. Looking back as a 23-year-old, she depicted herself as an exceptionally resilient young woman, who found the strength to overcome the stigma, violence and sexual abuse imposed by her primary carers. Yet, this self-depiction is only half the story, for our network analyses reveals how Mary's choices were channelled by shifting clusters of people who variously defined her as 'problematic', unwanted, 'special', 'filthy', 'talented' and a 'good' 'pupil' and 'friend'. As a young woman whose experience of parental affection was highly conditional, Mary did not initially know that the sympathy extended by adults could be motivated by the desire to isolate and exploit. Bill's abuse changed that, causing Mary to extend her distrust of social workers to most adult authority.

\section{Self-Blame as the 'Problematic Child'}

Up until her late teens, Mary's social network ensured she blamed herself for her problems, including the violence and sexual abuse to which she was subjected. It was professional intervention by healthcare workers that shifted Mary's identity from that of a 'child with problems' to a 'problematic child', unwittingly colluding with the wishes of her stepfather and mother who probably needed an explanation for her own excessive drinking behaviour that also concealed the domestic violence perpetrated by both of the men she had partnered. Later, as a teenager estranged from her family, Mary became a young woman with relationship problems which Bill blamed entirely on her. Again, the space between herself and the problems Mary was trying to manage was foreclosed by adults with secrets of their own; secrets that appeared to Mary to be under-scrutinized by the social workers monitoring her own behaviour. The consequence for Mary, as for so many young people subjected to social work intervention, was that the critical space needed to build relationships that were enduring 
and trustworthy enough to help her scrutinize the source of her problems diminished (Cossar et al, 2016). The impact on Mary was devastating. Behaviour that was symptomatic of the problems in her family home - insolence towards her mother, disruptiveness in school, sexual promiscuity, involvement in petty crime - merely confirmed Mary's labelling as a 'problematic' person who needed someone adept at 'saving' young people from themselves to rescue her, creating the window of opportunity for a predatory local 'hero' like Bill.

\section{The Significance of a New Network Offering Space}

This was why it took a new network, brokered a perceptive teacher, compassionate psychologist and an NGO with some freedom to respect Mary's wishes, to change Mary's understanding of her situation enough to empower her to break free of Bill. In combination, these three parties tipped the balance of power in Mary's network by offering a different kind of response to social services; a response that was not conditional on immediate compliance, but overtly responsive to Mary's own need for recognition as a good person who was justifiably distrustful of decisions 'made for her own good' by professionals. The NGO workers were also sensitive to Mary's understanding of the 'relationship' she was in, recognising that that she felt she had chosen, to some degree, to be with Bill and respecting her wish not to notify the police immediately. This calibrated support ultimately facilitated the emergence of a self-narrative in which Mary reorganised her story with a new unity and sense of purpose, premised around escaping abuse, overcoming the problems of her past and the possibilities offered by study and learning (Hermans and Hermans-Jansen, 1995; McAdams and McLean, 2013). Had Mary's teacher, psychologist and the NGO not responded to her tears, words and anxieties with compassion and curiosity, there is every chance that Bill would never have been convicted for abusing the young people in his care. Other cases made against him had failed because he was able to rally a network of adult professionals and vulnerable young people to testify to his good character. 


\section{Conclusion}

We opened this article by arguing that many of the questions that became pertinent in the 1980s - about the reach of social workers into the private lives of families and the risk of putting children and young people in greater danger following social work intervention remain pertinent today (Campbell, 1988; Munro, 2011). Despite the development of a considerable evidence base about how, where and when children disclose abuse, the barriers to disclosure and the complexities of tackling violence within 'relationships' that are inherently abusive, some children remain vulnerable to abuse even after they have been removed from family environments that placed that at risk.

\section{Envisioning Young People's Future Social Networks}

As Mary's case revealed, to safeguard children and young people effectively social workers need to know more than just how violent and abusive events come about. Practicing social workers need to be able to contemplate and envision the network of people within which young people will be repositioned after their interventions and how such networks will reconfigure the vulnerabilities and sources of support to which they are exposed. Anticipating how young people will be repositioned in such networks, as well as whether they can anticipate the difficult decisions such repositioning can present, should enable social workers to better anticipate where the opportunities for subsequent disclosures might lie. It might also enable them to strengthen relational practices in these areas so that they match and counter violence and sexual abuse that is also, by definition, relational in character, and sometimes definitive of the enduring connections between young people and those who have abused them, as it had become in Mary's relationship with Bill. Violence and abuse, as our analysis of Mary's case shows, are sometimes supported as much as they are challenged through response networks that are constituted through uneven manifestations of power in which 
abusers garner support from other parties who are complicit with their behaviour, afraid to speak out, or have reasons of their own to distrust or isolate victims.

\section{Widening the Focus of Intervention}

It is because social networks retain such capacities that interventions that focus exclusively on removing vulnerable children from the homes of potential perpetrators risk displacing the problem of child abuse rather than resolving it. To forestall such displacement social work interventions must engage with extrafamilial dynamics, such as harmful norms in peer groups, schools and public spaces anticipating, as far as possible, how vulnerable young people will reach out for support if confronted with prospective abusers who perceive young people's needs for belonging as an opportunity to exploit (Firmin, 2018b). What needs to be factored into understandings of the vulnerability of children exposed to sexual abuse are their ongoing experiences of the people responding to their abusers; responses that can consolidate feelings of distrust and betrayal formed within families where fear was pervasive, blame was displaced, and rejection was deployed as a tactic by adult carers keen to exclude children whose versions of events contradict their own. Calls for social workers to intervene more immediately and to share information between agencies more effectively are valid in this context, but they do not resolve the challenge of convincing young people that sources of support that previously failed them should be consulted again when perpetrators pose new threats or the shame of victimization resurfaces. Reorienting the focus of intervention to enhancing young people's access to wider networks of support, including that available through schools and NGOs, can go some way to overcoming obstacles lain through previous breaches of trust, unavoidable as they sometimes are (Robbins and Cook, 2018).

Reconciling Responsive and Responsible Responses 
The challenge for all those working with vulnerable young people remains one of balancing legal requirements to act responsibly - safeguarding against identifiable risks - and acting responsively - in ways that recognise the emotional needs of those exposed to physical and sexual abuse while conveying enough professional curiosity to be able to elucidate these needs fully (Burton and Revell, 2018). Young people's needs typically include the desire to retain some control over the consequences of disclosure, including how it impinges on the relationships in which they were abused, how they are subsequently defined, and whether these relationships will continue in some revised form. The difficulty for professionals is that in attempting to be responsive to the needs of vulnerable young people, they themselves risk sanctioning practices that entertain an immediate chance of revictimization. This occurred, for example, when Mary was permitted to modify her 'relationship' with Bill in anticipation of eventually 'ending' it.

One way of reconciling the tensions between responsible and responsive practice is to take full account of the wider social networks within which young people are going to be embedded post intervention. What we have shown, using the case of Mary, is that seemingly empathic responses to vulnerability - which can be impulsive, self-interested, governed by anger or fear, as well as containing, professionally curious and strategic - do have a significant impact upon how young people understand, talk and narrate experiences of being exposed to sexual abuse. The description of one's own and other's responses is one example of a response that can potentially be transformative for the individual concerned and the wider network of which they are part. Supporting young people through such unsettling processes is critical to protecting them from those who would use knowledge of their vulnerabilities against them and the backlash they can incur from those with vested interests in casting doubt on their testimonies. 
Using social network analysis, we have shown how Mary's network changed over time. When Mary was an infant this network was small and dominated by negative links with her family. Her violent father's departure was succeeded by the arrival of a stepfather who made Mary and her sister feel unwelcome in their own home and who encouraged their mother to attribute her excessive alcohol consumption to Mary's 'problematic' behaviour. When social services proposed placing Mary in institutional care after she had shared her view on the source of her problems, Mary presumed that her trust had been betrayed. Mary's network expanded to a youth club, which provided a new 'family' (of sorts) and one she welcomed until Bill's paternalistic care mutated into the demand for a sexual relationship that involved both rape and physical assaults. The network around Bill came to dominate Mary's life until another network of professional support enabled Mary to re-evaluate the stigma and violence that informed her perceptions of herself.

\title{
References
}

Arnett, J.J. (2004). Emerging adulthood: the winding road from the late teens through the twenties. New York: Oxford University Press.

\author{
Barter, C., Renold, E., Berridge, D., and Cawson, P. (2003). Peer Violence in Children's \\ Residential Care, Palgrave MacMillan: London.
}

Barter, C., McCarry, M., Berridge, D., and Evans, K. (2009). Partner exploitation and violence in teenage intimate relationships. London: NSPCC.

Burton, V. and Revell, L. (2018). Professional Curiosity in Child Protection: Thinking the Unthinkable in a Neo-Liberal World. The British Journal of Social Work 48, 6: 1508-1523. 
Campbell, B. (1988). Unofficial secrets, Child sexual abuse: The Cleveland case, London: Virago.

Côté, J.E. (1996). Sociological Perspectives on Identity Formation: The Culture-Identity Link and Identity Capital. Journal of Adolescence, 19: 417-428.

Côté, J.E. (2002). The Role of Identity Capital in the Transition to Adulthood: The Individualization Thesis Examined. Journal of Youth Studies 5: 117-134.

Cossar, J.; Brandon, M. and Jordan, P. (2016). 'You've got to trust her and she's got to trust you': Children's views on participation in the child protection system. Child and Family Social Work, 21: 103-112.

Crossley, N., Bellotti, E., Edwards, G., Everett, M., Koskinen, J. and Tranmer, M. (2015). Social Network Analysis for Ego-Nets. London, Sage.

Firmin, C. (2011). This is it. This is my life...Female Voice in Violence, Final Report London: ROTA.

Firmin, C. (2018a). Contextual Risk, Individualised Responses: An Assessment of Safeguarding Responses to Nine Cases of Peer-on-Peer-Abuse. Child Abuse Review, 27: 42-57.

Firmin, C. (2018b). Contextualizing Case Reviews: A Methodology for Developing Systemic safeguarding Practices. Child \& Family Social Work, 23: 45-52.

Furedi, F. (2013). Moral Crusades in an Age of Mistrust. Palgrave Macmillan: London. 
Gadd, D., Corr, M-L., Fox, C. L. and Butler, I. (2015). Young Men and Domestic Abuse, Routledge: London.

Gallagher, B. (2000). The extent and nature of known cases of institutional child sexual abuse, British Journal of Social Work, 30 6: 795-817.

Grund, T. U. (2015). nwcommands. Network Analysis in Stata. Retrieved 2 April 2018 from http://nwcommands.org.

Hermans, H. and Hermans-Jansen, E. (1995). Self-Narratives. The Construction of Meaning in Psychotherapy. The Guilford Press: New York.

Holt, S., Buckley, H. and Whelan, S. (2008). The impact of exposure to domestic violence on children and young people. Child Abuse \& Neglect, 32, 797-810.

Hydén, M. (2014). The teller-focussed interview: Interviewing as a relational practice. Qualitative Social Work, 13: 795-812.

Jay, A. (2014). Independent Inquiry into Child Sexual Exploitation in Rotherham (1997-2013).

Rotherham: Rotherham Metropolitan Borough Council. Retrieved 11 April 2018 from

https://www.rotherham.gov.uk/downloads/file/1407/independent inquiry cse in rotherham

La Fontaine, J.S. (1998). Speak of the Devil, Cambridge University Press: Cambridge.

McAdams, D.P. and McLean, K.C. (2013). Narrative Identity. Current Directions in Psychological Science, 22(3): 233-238. 
McCluskey, U. (2000). 'Abuse in Religious Institutions' in McCluskey, U. and Hooper, C-A. (eds), Psychodynamic Perspectives on Abuse: the Cost of Fear, pp 99-116, Jessica Kinglsey: London.

McElvaney, R. (2015). 'Disclosure of Child Sexual Abuse: Delays, Non-disclosure and Partial Disclosure. What the Research Tells Us and Implications for Practice', Child Abuse Review, 24: 159-169.

Miller, J. (2008). Getting Played: African American Girls, Urban Inequality and Gendered Violence New York University Press: New York.

Mollon, P. (2000). Postmodern Encounters: Freud and False Memory Syndrome, Totem: New York.

Munro, E. (2011). The Munro Review of Child Protection: Final Report. Retrieved 11th April 2018 from http://www.official-documents.gov.uk

Mullender, A., Hague, Iman, U., Kelly, L., Malos, E. and Regan, L. (2002). Children's perspectives on domestic violence. London: Sage.

Münger, A-C. (2016). 'The Best Interests of the Child' or the 'Best Interests of the Family'? How the Child Protection Services in Sweden Respond to Domestic Violence. In: Hydén, M., Gadd, D. and Wade, A. (eds.) Response Based Approaches to the Study of Interpersonal Violence. London: Palgrave Macmillan, p. 117-137. 
National Police Chief's Council (NPCC) (2018). Operant Hydrant: Football Abuse Statistics up to and Including 31st December 2017. Retrieved 11 April 2018 from

http://www.npcc.police.uk/NPCCBusinessAreas/OtherWorkAreas/OpHydrant/FootballAbuseSt ats.aspx.

Överlien C. and Hydén, M. (2009). Children's actions when experiencing domestic violence. Childhood. A Global Journal of Child Research, 16: 479-496.

Rayment-McHugh, S., Smallbone, S. and Tilley, N. (2015). Endemic Sexual Violence and Abuse Contexts and Dispositions. International Journal for Crime, Justice and Social Democracy, 4: 111-124.

Reavey, P and Gough, B. (2000). 'Dis/locating blame within the individual: women survivors talk about child sexual abuse, Sexualities 3: 325-346.

Robbins, R. and Cook, K. (2018). Don't Even Get Us Started on Social Workers': Domestic Violence, Social Work and Trust. British Journal of Social Work 48, 6: 1664-1681.

Riessman, C.K. (2008). Narrative Methods for the Human Sciences. Sage: Thousand Oaks, CA.

Sandberg, L. (2016). Caught in Between: Grandparents Responding to Violence and Negotiating Family Roles and Responsibilities. In: Hydén, M., Gadd, D. and Wade, A. (eds.) Response Based Approaches to the Study of Interpersonal Violence. Palgrave Macmillan: London, p. 98-116.

Stanley, N., Miller, P. and Foster Richardson, H. (2012). Engaging with children's and parents' perspectives on domestic violence. Child \& Family Social Work, 17, 192-201. 
Timmerman, G. (2003). 'Sexual Harassment of Adolescents Perpetrated by Teachers and by Peers', Sex Roles. A Journal of Research 48 (5-6), pp. 231-244.

Worrall, A., Boylan, J. and Roberts, D. (2008). SCIE Research briefing 25: Children's and young people's experiences of domestic violence involving adults in a parenting role. Social Care Institute for Excellence: London.

Yin, R.K. and Campbell, D.T. (2003). Case Study Research: Design and Methods. Thousand Oaks, CA: Sage.

\section{Figure Legends}

Figure 1: Network Around Mary During Childhood

Figure 2: Network Around Mary At Youth Club

Figure 3: Network Around Mary While Leaving Bill 


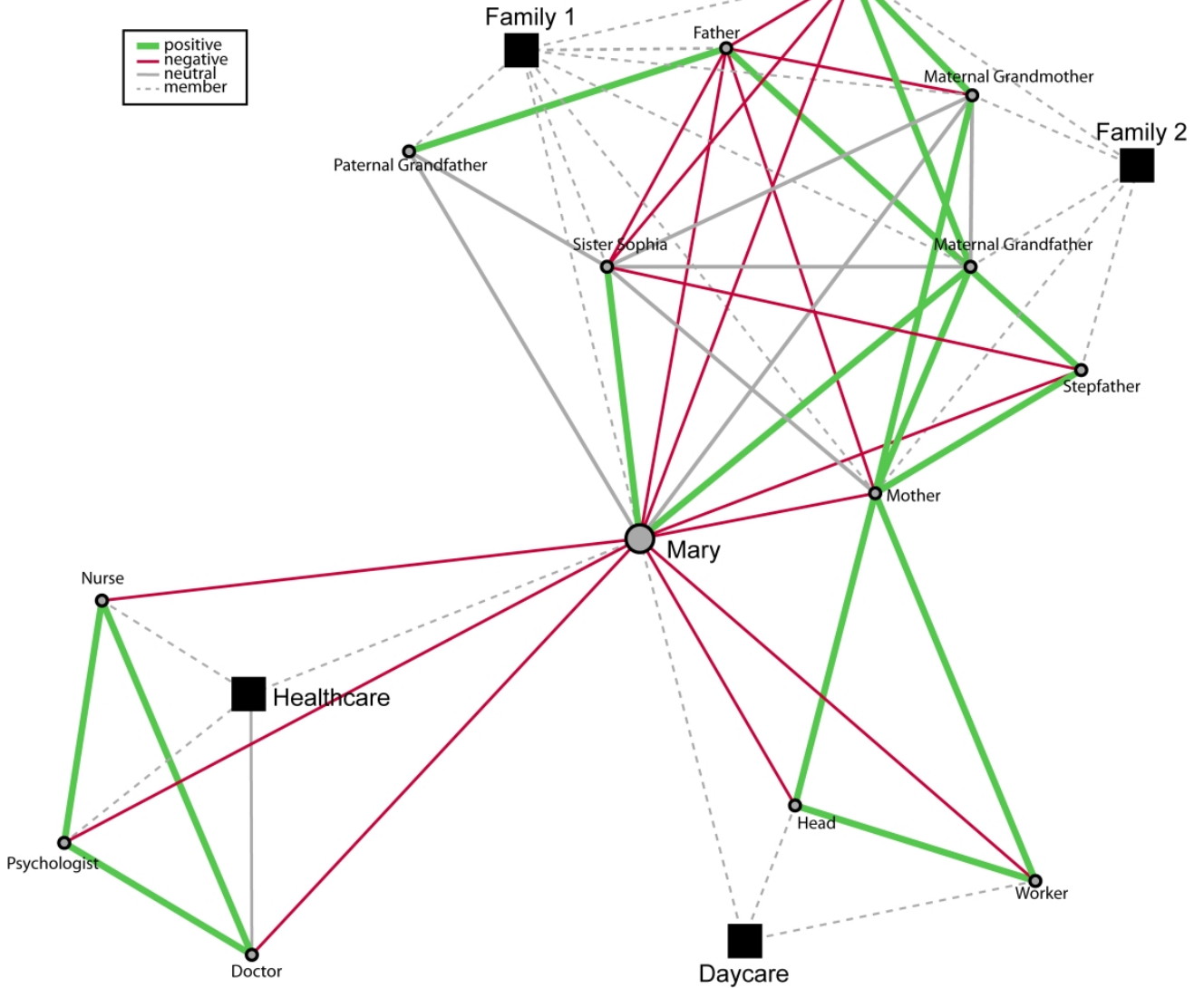

Figure 1: Network Around Mary During Childhood. 


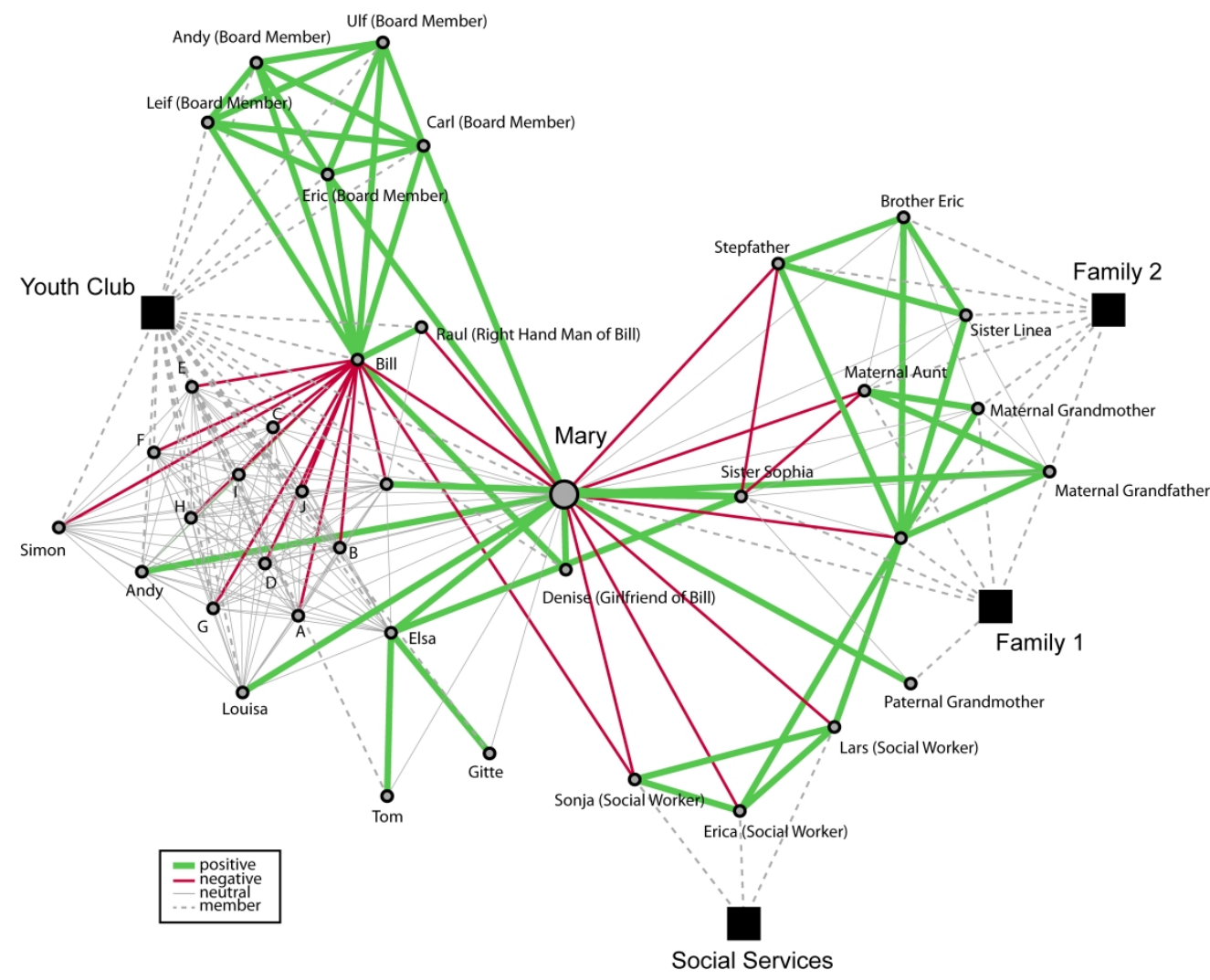

Figure 2: Network Around Mary At Youth Club. 


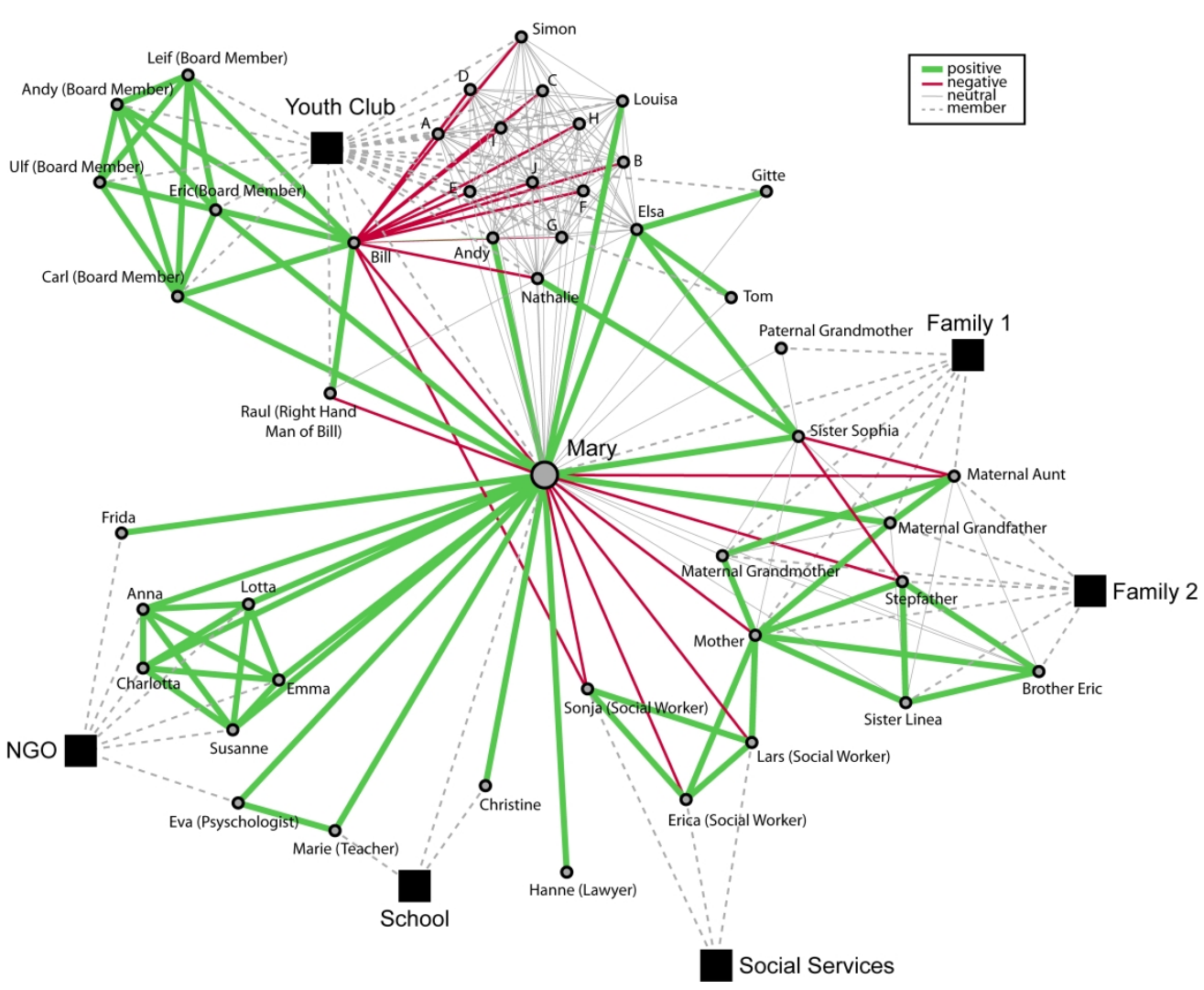

Figure 3: Network Around Mary While Leaving Bill. 